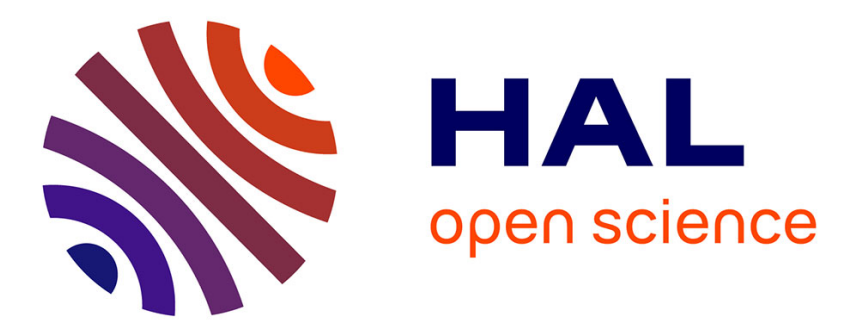

\title{
Flaring emissions in Africa: Distribution, evolution and comparison with current inventories
}

El Hadji Thierno Doumbia, Catherine Liousse, Sekou Keita, Louise Granier, Claire Granier, Christopher Elvidge, Nellie Elguindi, Kathy S. Law

\section{- To cite this version:}

El Hadji Thierno Doumbia, Catherine Liousse, Sekou Keita, Louise Granier, Claire Granier, et al.. Flaring emissions in Africa: Distribution, evolution and comparison with current inventories. Atmospheric Environment, 2019, 199, pp.423-434. 10.1016/j.atmosenv.2018.11.006 . hal-02116054

\section{HAL Id: hal-02116054 \\ https://hal.science/hal-02116054}

Submitted on 10 Nov 2020

HAL is a multi-disciplinary open access archive for the deposit and dissemination of scientific research documents, whether they are published or not. The documents may come from teaching and research institutions in France or abroad, or from public or private research centers.
L'archive ouverte pluridisciplinaire HAL, est destinée au dépôt et à la diffusion de documents scientifiques de niveau recherche, publiés ou non, émanant des établissements d'enseignement et de recherche français ou étrangers, des laboratoires publics ou privés. 
Thierno Doumbia(1)

Catherine Liousse ${ }^{(2)}$

Sekou Keita ${ }^{(2)}$

Louise Granier ${ }^{(2)}$

Claire Granier ${ }^{(1,2,3)}$

Christopher D. Elvidge ${ }^{(4)}$

Nellie Elguindi(2)

Kathy Law ${ }^{(1)}$

1) LATMOS/IPSL, UPMC Univ. Paris 06 Sorbonne Universités, UVSQ, CNRS, Paris, France

2) Laboratoire d'Aérologie, OMP-CNRS, Toulouse, France

3) NOAA/ESRL/CSD and CIRES, Boulder, CO, USA

4) Earth Observation Group, National Centers for Environmental Information, National Oceanic and Atmospheric Administration, Boulder, CO, USA

Contact email: thiernodoumbia@yahoo.fr 
51 Flaring emissions are a major concern due to large uncertainties in the amount of chemical compounds released into the atmosphere and their evolution with time. A methodology based on DMSP (Defense Meteorological Satellite Program) nighttime light data combined with regional gas flaring volumes from National Oceanic and Atmospheric Administration's National Centers for Environmental Information (NOAA-NCEI) has been developed to estimate flaring emissions. This method is validated in Nigeria where individual field company data are available. The spatial distribution of $\mathrm{CO}_{2}, \mathrm{CH}_{4}, \mathrm{NMVOCs}, \mathrm{CO}, \mathrm{OC}, \mathrm{BC}$, $\mathrm{SO}_{2}$ and $\mathrm{NO}_{\mathrm{x}}$ is derived for the African continent for the period 1995-2010.

A range of the emissions due to flaring is estimated based on the range of emission factors (EFs) for each chemical species. An average decrease in $\mathrm{CO}_{2}$ emissions of about $30 \%$ is found over Africa from 1995 to 2010, with Nigeria being the largest contributor to this reduction (up to $50 \%$ ). Changes in the spatial distribution with time indicate local increases, particularly at offshore platforms, which are attributed to a lack of regulations as well as aging infrastructures in oil and gas fields.

Comparisons with current inventories reveal differences in the location and magnitude of point source emissions. For chemical compounds such as NMVOCs and $\mathrm{CH}_{4}$, the ECLIPSE and EDGAR country-level values are considerably higher than the highest flaring emission estimated in this study for 2005. For species such as $\mathrm{CO}, \mathrm{OC}, \mathrm{BC}, \mathrm{SO}_{2}$ and $\mathrm{NO}_{\mathrm{x}}$, the emissions provided by the ECLIPSE and EDGAR inventories are generally within the same order of magnitude as the average values found in this study, with the exception of OC, BC and $\mathrm{SO}_{2}$ in which EDGAR provides much lower emissions. These discrepancies are likely due to either differences in the methodologies used to estimate the emissions, in the values of the emission factors considered, or in the definition of flaring sector. Our current estimations suggest that $\mathrm{BC}, \mathrm{CH}_{4}$ and $\mathrm{CO}_{2}$ flaring emissions in Africa account for $1-15 \%$ (on average 7 $\%$ ), 0.5-8 \% (on average $2 \%$ ) and 8-13\% (on average $11 \%$ ) of African total anthropogenic emissions, respectively. The contribution of flaring to African anthropogenic emissions varies widely among countries. For example, in Nigeria the average emissions due to flaring are estimated to be as high as $18 \%$ for $\mathrm{BC}, 10 \%$ for $\mathrm{CH}_{4}$ and $50 \%$ for $\mathrm{CO}_{2}$, which is significantly greater than the continental average and highlights the importance of emissions in flaring areas.

82 Keywords: Defense Meteorological Satellite Program (DMSP), nighttime light, flaring, 


\section{Introduction}

During the past few decades, crude oil/gas explorations have been shown to have large socioeconomic, environmental and health impacts on local populations (Waldner et al., 2001 ; Nwaogu and Onyeze, 2010 ; Wilk and Magdziarz, 2010 ; Nwankwo and Ogagarue, 2011). One of the major issues linked to these activities is gas flaring. Flaring is a process during which natural gas or associated gas (which co-exists with oil in a primarily oil field) that is deemed uneconomical to collect and sell is burned at a high temperature (Johnson et al., 2001 ; Talebi et al., 2014). It is also used to burn gases that would otherwise present a safety problem. For example, natural gas that contains hydrogen sulfide $\left(\mathrm{H}_{2} \mathrm{~S}\right)$ is routinely flared in order to convert the highly toxic $\mathrm{H}_{2} \mathrm{~S}$ gas into less toxic compounds. These processes, used extensively in oil/gas refineries, may lead to large emissions of air pollutants consisting of unburned fuel components (e.g. methane $\left(\mathrm{CH}_{4}\right)$, non-methane volatile organic compounds (NMVOCs)), by-products of combustion (e.g. black carbon (BC), organic carbon (OC) and partially combusted substances such as carbon monoxide $(\mathrm{CO})$, carbon dioxide $\left(\mathrm{CO}_{2}\right)$, nitrogen oxides $\left(\mathrm{NO}_{\mathrm{x}}\right)$ ) and sulfur dioxide $\left(\mathrm{SO}_{2}\right)$ (McEwen and Johnson, 2012 ; Johnson et al., 2013 ; Davoudi et al., 2013). An estimated 140-150 billion cubic meters (BCM) of gas is flared or vented globally each year, representing approximately $70 \%$ of the natural gas production in Africa in 2011 (IEA, 2016). The economic loss due to these practices is about \$30-35 billion per year worldwide, and about \$2.5 billion in Nigeria (Ite and Ibok, 2013). Africa, particularly in the Niger Delta and northern regions, has many natural resources that include large crude oil/gas reserves which has attracted the interest of international petroleum companies since the 1950s. Six African countries (Nigeria, Algeria, Angola, Libya, Gabon and Egypt) are among the top 20 countries in the world that use flaring, with Nigeria being the largest one in Africa and the second largest in the world (Elvidge et al., 2009), despite the fact that flaring has been legally banned there since 1984. Most flaring occurs in developing countries where there is a lack of market and infrastructure in place to recycle, transport and sell the associated gas.

The spatial distribution and evolution of flaring emissions are not well characterized and poorly quantified, if they exist at all, in many current global and regional inventories. Among current inventories, the amount of emission varies significantly. According to Stohl et al. (2013), the amount of BC from gas flares was approximately 228 kiloton (kt) in 2010, representing about $3 \%$ of the total global BC anthropogenic emissions (7109 kt) as given by the ECLIPSEv5a inventory (Stohl et al., 2015). At the other extreme, Weyant et al. (2016) 
118 reported a much lower estimate of total global BC flaring emission $(20 \pm 6 \mathrm{kt})$ than that of

119 Stohl et al. (2013). The large uncertainty, or even absence in some cases, of flaring emissions 120 that exists in current inventories can lead to large disparities when comparing models and 121 satellite observations, as documented in studies over regions such as the Niger Delta which 122 are heavily influenced by large flaring activities (Liousse et al., 2010 ; Malavelle et al., 2011). 123 Uncertainties in flaring emissions in current inventories are mainly due to limited access to 124 official flaring volume records and to the lack of field measurements of representative emission factors (EFs). Up until now, only a few limited studies based on satellite observations or modeling simulations have been performed in order to provide estimates of the amount and spatial distribution of flaring emissions. In this paper, we use nighttime lights as a proxy for the determination of the spatial distribution of flaring emissions in Africa and their evolution over time (1995-2010). Nighttime light data, collected by the US Defense Meteorological Satellite Program (DMSP), have been used to measure the human footprint over the world since 1992. Data collection ceased in 2012 due to the natural degradation of the DMSP satellite sensors.

The goal of this study is to develop a detailed analysis of the quantity and spatial distribution of emissions of different atmospheric compounds resulting from flaring activities. The methodology described in Section 2 is first applied and validated over the Niger Delta where oil companies provide publicly available data. After presenting a review of the emission factors, in Section 3 we present the spatial distribution and trends of flaring emissions in Africa, followed by a comparison with other flaring emissions data provided from other sources, namely the ECLIPSE (Stohl et al., 2015) and EDGAR (Janssens-Maenhout et al., 2013) inventories. Finally, the contributions of flaring to the total anthropogenic emissions in Africa are discussed.

\section{Methodology}

\subsection{Distribution of flaring volumes from DMSP satellites}

The DMSP satellites provide global nighttime light coverage every 24 hours from 1992-2012 (http://ngdc.noaa.gov/eog/dmsp/). The images, captured through a sensor called Operational Linescan System (OLS), were inter-leaved to obtain yearly composites covering the whole world. Two satellites orbiting simultaneously, each with a lifespan of 6 to 8 years, provided 32 composites between 1992 and 2011. Each pixel of the composite images has a resolution 
150 of 30 arcseconds, corresponding to approximately 0.86 square kilometers at the equator. The 151 DMSP satellites provide different types of data, including worldwide cloud cover, radiance 152 calibrated data, stable lights and average lights multiplied by the percent of light detection 153 (avg_x_pct), which are used to infer national flaring volumes (Elvidge et al., 2009). This 154 latter product represents the most extensive time series available for estimating national and 155 global magnitudes of flared activity. The avg_x_pct images give a global distribution of the 156 average visible band Digital Number (DN), with values ranging from 0 to 63, reflecting the 157 brightness of light. Generally, because flares are very bright, large flares are more likely to be 158 captured by the images.

159 A Geographic Information System (ArcGIS software, ESRI 2014) is utilized to derive yearly 160 spatial distributions of gas flare volumes. A schematic diagram of the methodology employed 161 is presented in Figure 1 and detailed step-by-step in the following paragraphs:

163 1. Avg_x_pct images: The satellite composite images are the primary data used in this study. 164 First, if two composites are available for a single year, a calibration following the recommendations given by Elvidge et al. (2009) is performed. Large changes can be observed between different years resulting from the aging of on-board electronics, particularly the sensors. An equation for inter-calibrating yearly nighttime light products determined by

168 Elvidge et al. (2009) is applied to the data to adjust the Digital Number (DN) values.

169 Following this adjustment, when two satellites provided images for the same year, an average

170 of these two images is performed. In order to minimize the background noise and reduce 171 saturation effects, DN values lower than 9 and higher than 60 are removed from the 172 avg_x_pct files (Elvidge et al., 2009).

174 2. Gas flare areas: Some issues remain with the avg_x_pct images because city lights are still 175 present in the data which can be problematic in areas where there are oil/gas platforms located 176 over land. To correct this problem, pixels with city lights in the avg_x_pct images are 177 identified using maps featuring the location of gas flare areas and are excluded from the 178 analysis. These maps are obtained from a group of shapefiles (one per country) downloaded 179 from the NOAA-NCEI website 180 (http://ngdc.noaa.gov/eog/interest/gas flares_countries_shapefiles.html). The country-level 181 maps are merged using ArcGIS tools to create a unique dataset of flaring locations over 182 Africa that is used for all years. Unfortunately, for some countries the shapefiles are out-of183 date and do not cover all flaring areas, nevertheless they represent the best data available in 
184 the literature at the time of this study for the period of interest. The newly created shapefile is 185 then used to mask pixels outside the flaring areas, which are assumed to be city lights and are 186 thus excluded from the analysis.

3. World maritime boundaries: This step accounts for the volumes of flaring from onshore and offshore oil/gas platforms. Information on world maritime boundaries is used 190 (http://www.marineregions.org/downloads.php) to attribute each offshore platform to a country by combining avg_x_pct over gas flare areas from step 2 and the maritime boundaries shapefile.

4. Weighted coefficients within each grid cell for each country: This is calculated as the ratio between the light intensity within a grid cell quantified in step 3 and the total DN within a country as determined in step 1 .

198 5. National flaring volumes: Elvidge et al. (2009) have estimated the yearly volume of gas 199 flared from 1994 to 2010 for each country. The error associated with each national volume is 200 also provided, generally ranging from 2 to 3 billion cubic meters (BCM) for African 201 countries. These data are available from the NOAA-NCEI website previously indicated;

203 6. Gridded flaring volumes: We obtain gridded files by multiplying the volume of gas flared 204 at the country-level from step 5 by the weighted coefficients calculated in step 4. A grid of 205 polygons consisting of multiple grid cells of $0.1^{\circ} \times 0.1^{\circ}$ resolution is defined. Then, the mean 206 volume is calculated in each polygon;

208 The main uncertainties associated with this methodology are 1) the identification of flares 209 from lights based on gas flaring shapefiles only, and 2) the use of national flaring volumes 210 that are derived themselves from nighttime data. These data contain uncertainties regarding 211 the quantities of flares that are identified and the effectiveness of the conversion from light 212 brightness to flared volume. In addition, some small flares and flares that are too bright might be missed due to background noise and saturation effects removal, respectively. 


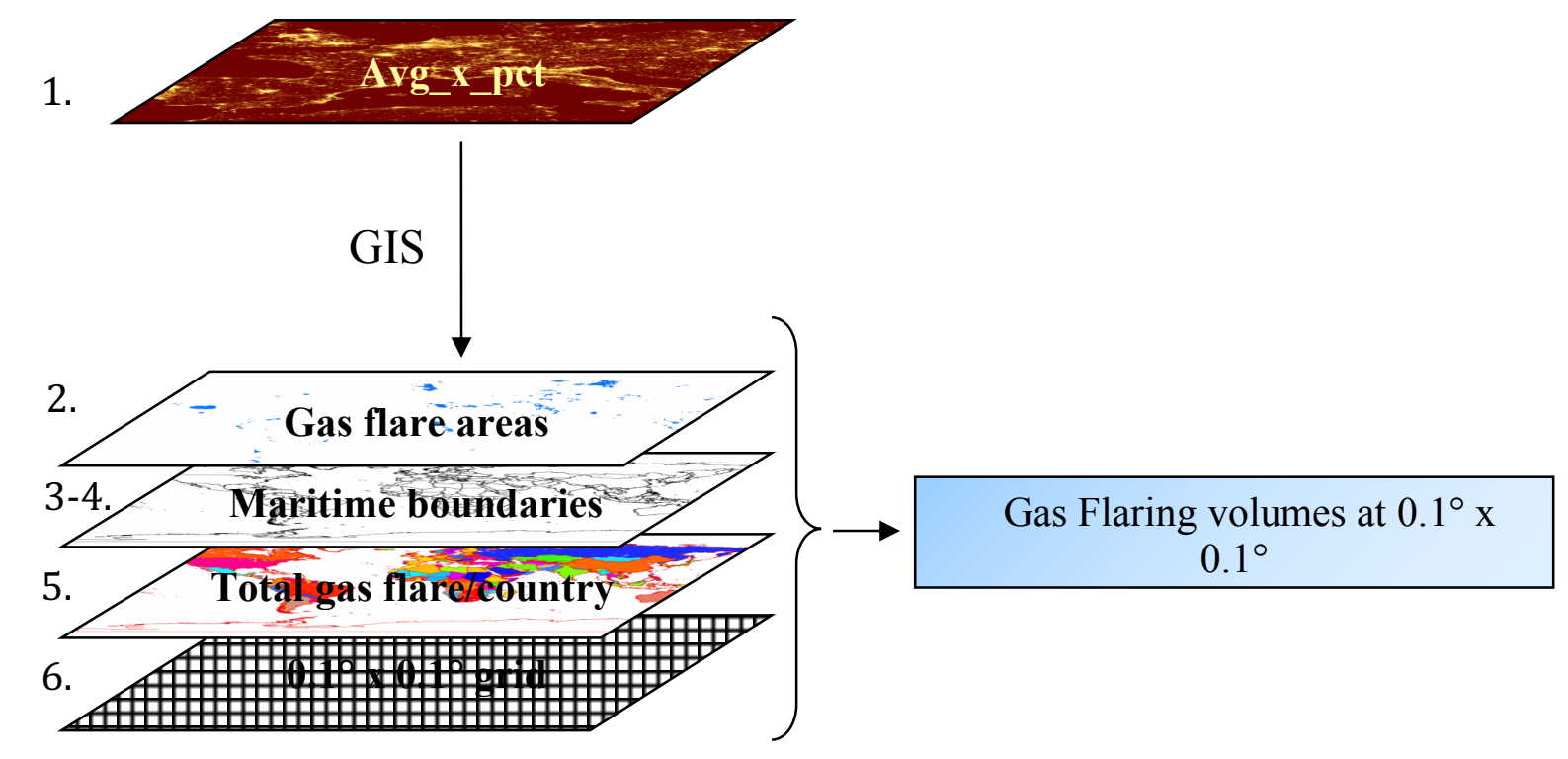

214

215

Figure 1: Schematic view of the methodology used to derive the spatial distribution of flaring volumes using DMSP satellite data.

\subsection{Comparison with field company data: validation in the Niger Delta}

In order to validate our methodology, a comparison between flaring volumes obtained from this work with those provided in the Nigerian National Petroleum Corporation (NNPC) 2011 report was performed. NNPC collects the quantities of oil/gas produced, used and flared as communicated by different oil companies such as Shell, Mobil, Chevron, Texaco, SNEPCO, NAOC, NAE, Esso, AENR, Pan-Ocean and Elf_Total, operating in the Niger Delta. Statistical data are published on an annual basis as bulletins, which are available at: http://www.nnpcgroup.com. The geographic coordinates of oil/gas fields from the report are used to verify the accuracy of the location of flares by comparing them with the position of nighttime light intensities (avg_x_pct image) (Figure 2). We compare 2011, the most recent year with available and exploitable DMSP world nighttime light images and flaring volumes for Nigeria (Elvidge et al., 2015). A good consistency in the location of flares is found between the two datasets (Figure 2). Both the oil/gas companies and the DMSP data highlight three major oil/gas activity zones in the Niger Delta: southwest, southeast and north central. As can be seen in Figure 2, the DMSP data provide a more extensive and accurate coverage of flaring areas than the data reported in the literature. Differences between the datasets can be explained by the fact that 1) NNPC does not represent all oil companies in the Niger Delta, 2) oil company data do not take into account the non-official (e.g. indigenous or black market, 
etc.) oil/gas activities, which are very important in Nigeria, and 3) processing composite

237 images using the method described in this study may result in the removal of potential flare

238 lights. Moreover, nighttime city lights, which are present in the satellite images, could lead to 239 misinterpretation of flare locations over land areas despite our attempts to minimize this 240 source of error.

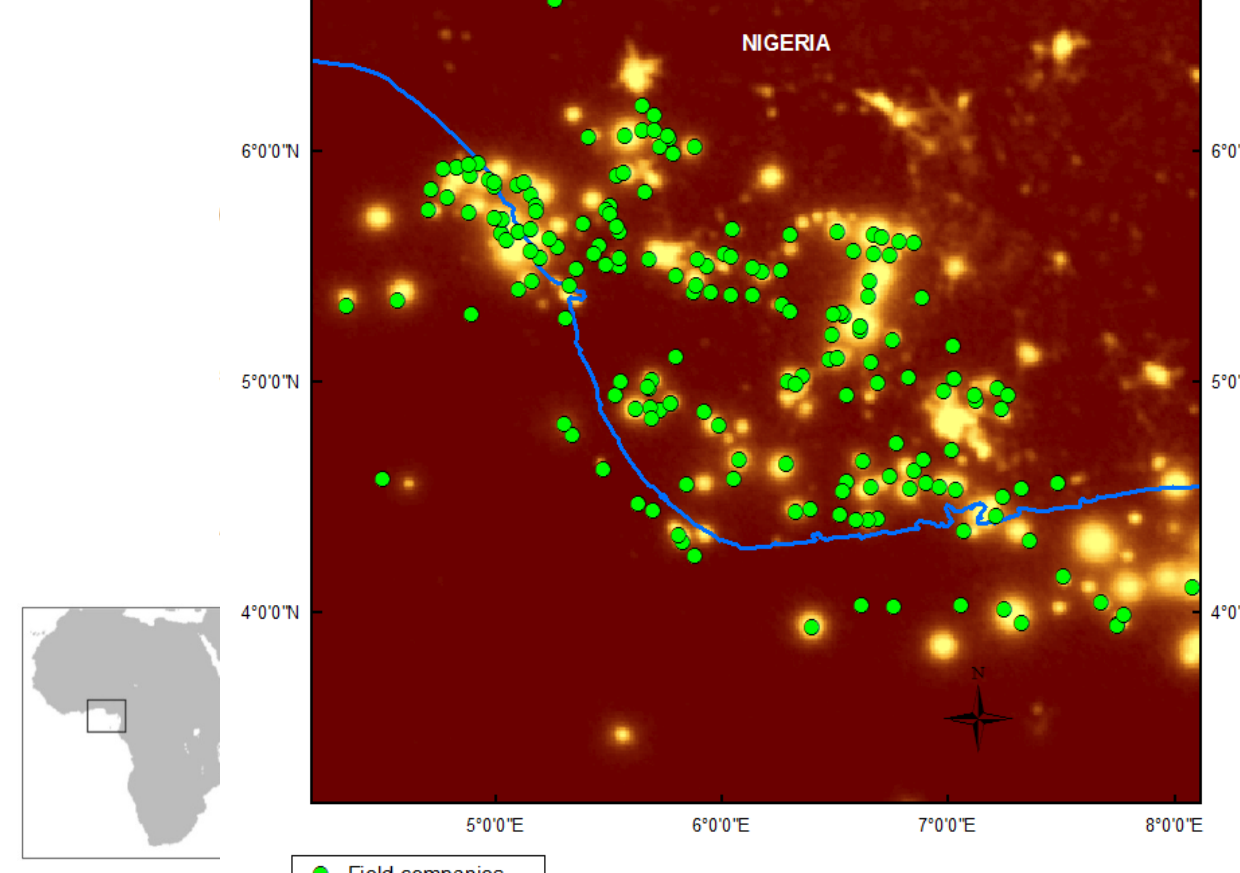

243 Figure 2: Geolocation of the oil/gas fields (in green) in the Niger Delta from the NNPC 2011

244 annual statistics bulletin superimposed on the avg_x_pct image for the same year from the 245 DMSP satellites (in yellow-brown). The markers represent the different multinational oil 246 companies.

248 Figure 3 compares gas flaring volumes sampled/extracted at each flare location using 249 latitude/longitude coordinates of oil/gas fields (Figure 3, left) with individual flare volumes provided by agency sources (Figure 3, right). Both DMSP satellite and field company data 251 clearly confirm the three major flaring areas previously identified in the Niger Delta, with 252 flaring volumes reaching more than 100 million cubic meters (MCM) in most areas. These 253 data also illustrate large amounts of flaring volumes emitted along the coast of Nigeria, with 254 the highest volumes concentrated on offshore platforms. In comparing individual oil/gas 255 stations, flaring volumes estimated in this work are consistent with values provided by field 256 companies (only $6 \%$ difference). However, the total gas flared in Nigeria reported by the 257 NNPC for 2011 is 17.5 billion $\mathrm{m}^{3}$, about $20 \%$ higher than the value of 14.6 billion $\mathrm{m}^{3}$ 
estimated from satellite measurements. This $20 \%$ difference is on the same order of magnitude as the largest error $\left(3\right.$ billion $\mathrm{m}^{3}$ ) of the estimated regional gas flaring volumes from DMSP satellites. When considering only offshore platforms, the amount of flaring from this study is on average $28 \%$ higher than that reported in the field company data. The differences are considerably less for onshore fields where the reports are approximately $13 \%$ higher the values found using our methodology. This supports the fact that possible flare points were removed during the processing of nighttime light images and data concerning offshore fields are likely missing from the NNPC reports. Overall, we find a reasonable agreement between the calculated amount of gas flared in the Niger Delta and what is reported, thus giving confidence to our methodology which we extended to the rest of Africa as presented in Section 3.
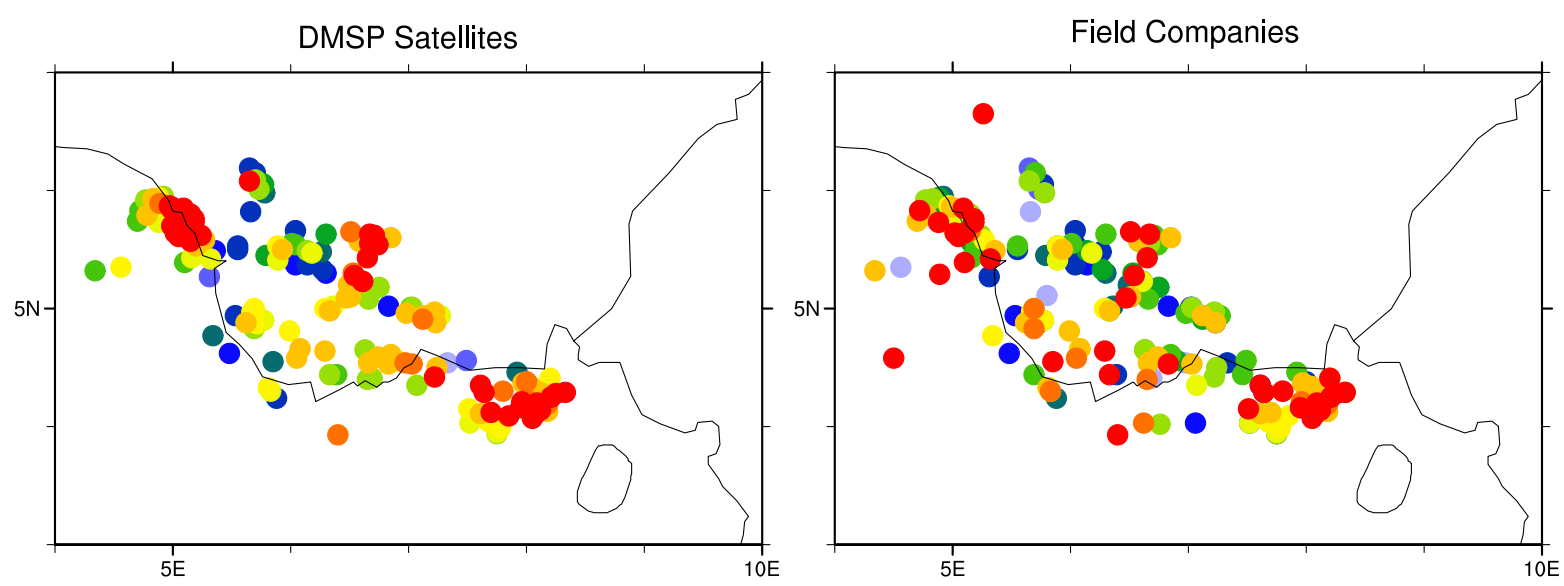

Figure 3: Comparison of flaring volumes in million cubic meters $(\mathrm{mcm})$ in 2011 between reporting NNPC data (right) and estimated values from DMSP satellite observations over the Niger Delta (left).

\subsection{Flaring emission estimates}

277 Emissions from gas flaring are calculated using the following equation:

$$
\mathrm{X}_{\text {flaring }}=\mathrm{GF}_{\text {volume }} * \mathrm{X}_{\mathrm{EF}} * \mathrm{~d}_{\mathrm{f}}
$$

279 where $\mathrm{X}_{\text {flaring }}$ is the emission rate of a pollutant $\mathrm{X}$ (kiloton), GF $\mathrm{volume}_{\text {is }}$ is the volume of gas 280 flared in billion of cubic meter ( $\mathrm{bcm})$. The volume of gas flared at each grid cell is estimated 281 from remote sensing data following the methodology described in section 2.1. $\mathrm{X}_{\mathrm{EF}}$ is the emission factor $(\mathrm{EF})$ in $\mathrm{g}$ of species per $\mathrm{kg}$ of gas flared. The EF depends on many factors 
including the quantity/quality and the composition of the fuel burned, the combustion devices and the operation conditions (Torres et al., 2012). Finally, $\mathrm{d}_{\mathrm{f}}$ is the density of the fuel gas, typically varying between 0.75 and $1.2 \mathrm{~kg} / \mathrm{m}^{3}$ depending on the fraction of heavy hydrocarbons present in the fuel (US Standard Atmosphere, 1976). In this paper, we assume a gas density $\mathrm{d}_{\mathrm{f}}$ of $0.8 \mathrm{~kg} / \mathrm{m}^{3}$ (E\&P Forum, 1994). Due to the characterization of all these parameters, determining emission rates of chemical compounds emitted during flaring processes can be quite challenging, especially because very few field measurements exist that are publicly available. Most of the EFs published in the literature concern industrial flares from petroleum refineries, chemical plants, natural gas processing industries, and oil and gas extraction. The EFs discussed within the framework of this study were taken from the literature, and were obtained using different techniques such as direct field and laboratory measurements, model estimates generally evaluated using data from laboratory experiments, and estimations by applying data from company's facilities. Direct measurements from field companies are difficult to obtain if they exist at all. This suggests that the EFs reported here have a great deal of uncertainty. For these reasons, low and high values are used in order to be representative of all flaring types.

Table 1 gives a review of EFs for various species $\left(\mathrm{CH}_{4}, \mathrm{NMVOC}, \mathrm{CO}, \mathrm{CO}_{2}, \mathrm{NO}_{\mathrm{x}}, \mathrm{SO}_{2}, \mathrm{OC}\right.$ and BC) published in the literature. For most areas, the composition of flared gas is not well known and most of the species cited were not directly analyzed. For example, $\mathrm{SO}_{2}$ is formed when fuel containing hydrogen sulfide compounds (such as $\mathrm{H}_{2} \mathrm{~S}$ ) are burned. The EF for $\mathrm{SO}_{2}$ is based on the assumption that sulfur content in the flared gas is known. Table 1 shows a large range of $\mathrm{BC}$ EFs, reflecting the different approaches that have been used for their estimation according to specific conditions. Weyang et al. (2016) estimate the lowest BC EF, with a value of $0.14 \mathrm{~g} / \mathrm{kg}$. This value is based on field measurements from associated gas using a Single Particle Soot Photometer in North Dakota, USA. The upper bound of $3.2 \mathrm{~g} / \mathrm{kg}$, which is reported by the Canadian Association of Petroleum Producers (CAPP, 2014), is based on measurements of particulate matter from landfill flares. It is very close to the highest estimated BC EF of $3.1 \mathrm{~g} / \mathrm{kg}$ reported by Weyang et al. (2016), which was measured using a three-wavelength Particle Soot Absorption Photometer. Differences in the method used to estimate EFs for BC and other chemical species add another level of uncertainty to the large

314 range of values found in the literature. Similar to BC, there is also a great deal of variability 315 in the EFs for $\mathrm{CH}_{4}$ and $\mathrm{SO}_{2}$, while for the remaining species (CO, $\mathrm{CO}_{2}, \mathrm{NO}_{\mathrm{x}}$ and $\left.\mathrm{NMVOC}\right)$ 316 the minimum EF is 2-5 times lower than the highest value. For OC, we consider the EF as a 
317 fraction of that of particulate matter (PM) (Statistics Norway, 2013). In their calculation, it is 318 assumed that 1) $\mathrm{PM}_{2.5}$ is approximately equal to the sum of $\mathrm{BC}$ and organic matter $(\mathrm{OM}=$ $3191.4 * \mathrm{OC}$ ) and 2) the amount of $\mathrm{BC}$ is equal to the amount of OM. Therefore, using an EF of $3201.07 \mathrm{~g} / \mathrm{kg}$ for $\mathrm{PM}_{2.5}$ as taken from the Norwegian national inventory, and an $\mathrm{EF}$ of $0.85 \mathrm{~g} / \mathrm{kg}$ 321 for BC based on McEwen and Johnson (2012). Statistics Norway, (2013), we derived an OC 322 EF equal to $0.15 \mathrm{~g} / \mathrm{kg}$.

323 In order to assess the impact of the large uncertainties associated with the EFs, we provide a 324 range of flaring emission estimates using both the lowest and highest EFs. The average 325 emissions are calculated based on the mean EF given in Table 1 and will be used for the 326 comparisons. 
Table 1: Review of the literature emission factors (EF) (in $\mathrm{g} / \mathrm{kg}$ ) for industrial flares for different species.

\begin{tabular}{|c|c|c|c|c|c|c|c|c|}
\hline References & $\mathrm{CO}$ & $\mathrm{CO}_{2}$ & $\mathrm{CH}_{4}$ & $\mathrm{NO}_{\mathrm{x}}$ & NMVOC & $\mathrm{SO}_{2}$ & $\mathrm{OC}$ & $\mathrm{BC}$ \\
\hline Allen and Tores, 2011 & $5.95-11.87$ & & & $1.05-2.98$ & & & & \\
\hline CAPP, 2014 & & & & & & & & 3.2 \\
\hline CONCAVE, 2009 & 8.2 & & & 1.4 & 5 & & & \\
\hline CORINAIR, 2002 & & & 2.5 & & & & & \\
\hline US EPA, $1991 \& 1996$ & 7.99 & & 20 & 1.5 & 3 & & & 0.33 \\
\hline US EPA, 2015 & 6.7 & 3200 & 3 & 1.5 & 12.3 & & & \\
\hline EEMS, 2008 & 6.7 & 2800 & $10-45$ & 1.2 & $5-10$ & 0.013 & & \\
\hline E\&P Forum, 1994 & 8.7 & 2610 & 35 & 1.5 & 15 & 0.013 & & \\
\hline Martin et al., 2003 & & 2400 & & & & & & \\
\hline $\begin{array}{l}\text { McEwen \& Johnson, } \\
2012\end{array}$ & & & & & & & & 1.05 \\
\hline UK NAEI & 5.15 & & & 1.1 & 5 & 0.12 & & \\
\hline OLF, 2012 & 18 & 3200 & & 3.7 & 3.3 & 0.13 & & 0.64 \\
\hline Fawole et al., (2016) & $7.78-10.08$ & $1980-3365.5$ & & & & & & $0.58-1.7$ \\
\hline Ras et al., 2012 & & & & & & & & 0.64 \\
\hline SN, 2013 & & & & & & & 0.15 & 0.85 \\
\hline Stohl et al., 2013 & & & & & & & & 2 \\
\hline Weyant et al., 2016 & & & & & & & & $0.14-3.1$ \\
\hline Min & 5.15 & 1980 & 2.5 & 1.05 & 3 & 0.013 & 0.15 & 0.14 \\
\hline Max & 18 & 3365.5 & 45 & 3.7 & 15 & 0.13 & 0.15 & 3.2 \\
\hline Mean & 8.83 & 2793.64 & 19.25 & 1.77 & 7.32 & 0.07 & 0.15 & 1.29 \\
\hline
\end{tabular}

CAPP: Canadian Association of Petroleum Producers

CORINAIR: CORe INventory AIR emissions

CONCAWE: CONservation of Clean Air and Water in Europe

EEMS: Environmental Emissions Monitoring System

E\&P Forum: oil/gas Exploration \& Production, actual Association of Oil \& Gas producers (OGP)

US EPA: United States Environmental Protection Agency

UK NAEI: Unite Kingdom National Atmospheric Emission Inventory

OLF: Oliearbeidernes Fellessammensltning (Norwegian Oil Industry Association)

SN: Statistic Norway 


\section{Results}

\subsection{Spatial distributions of flaring emissions in Africa}

339 We have estimated the emissions for Africa from 1995 to 2010, the period for which the data 340 are available, at a $0.1^{\circ} \times 0.1^{\circ}$ grid resolution.

341 Flaring emissions occur in two major parts of Africa; the north, which we refer to as Region I,

342 includes Algeria, Tunisia, Libya and Egypt, and the southwest, referred to as Region II, which 343 includes Nigeria, Equatorial Guinea, Gabon, Democratic Republic of Congo (DRC) and 344 Angola (Figure 4). $\mathrm{CO}_{2}$ has been reported to be one of the largest atmospheric pollutants emitted during flaring activities. This is confirmed by its higher EF compared to other chemical compounds (Table 1). Figure 4 displays the spatial distribution of the average estimated $\mathrm{CO}_{2}$ flaring emissions for 1995, with the largest values occurring in Nigeria as well as a few hotspots in Algeria and Libya.

349 Trends in $\mathrm{CO}_{2}$ emissions vary spatially as indicated by the spatial distribution of the 350 differences in $\mathrm{CO}_{2}$ flaring emission between 1995 and 2010 (Figure 5). A significant 351 reduction is seen in many areas, reaching up to $4 \mathrm{Tg}$. However, we also note local increases 352 in several locations of up to $2.5 \mathrm{Tg}$, namely along the coastal areas of the Niger Delta, 353 Equatorial Guinea, Gabon, DRC and Angola, as well as on offshore platforms and onshore 354 fields situated in region I (Figure 5). Several factors likely contribute to these local increases, 355 including offshore concessions development to expand deepwater oil extraction and avoid 356 security concerns, particularly in the Niger Delta. Also, it is more difficult for the governments to regulate offshore activities (McLennan and Williams, 2005 ; EIA, 2016). Consequently measures to reduce flaring emissions in these production areas are partially, or not all, implemented. The observed increase in inland areas may result from the lack of flaring reduction implementation policies, in addition to the aging infrastructures of oil and gas fields in several flaring countries in Africa. 


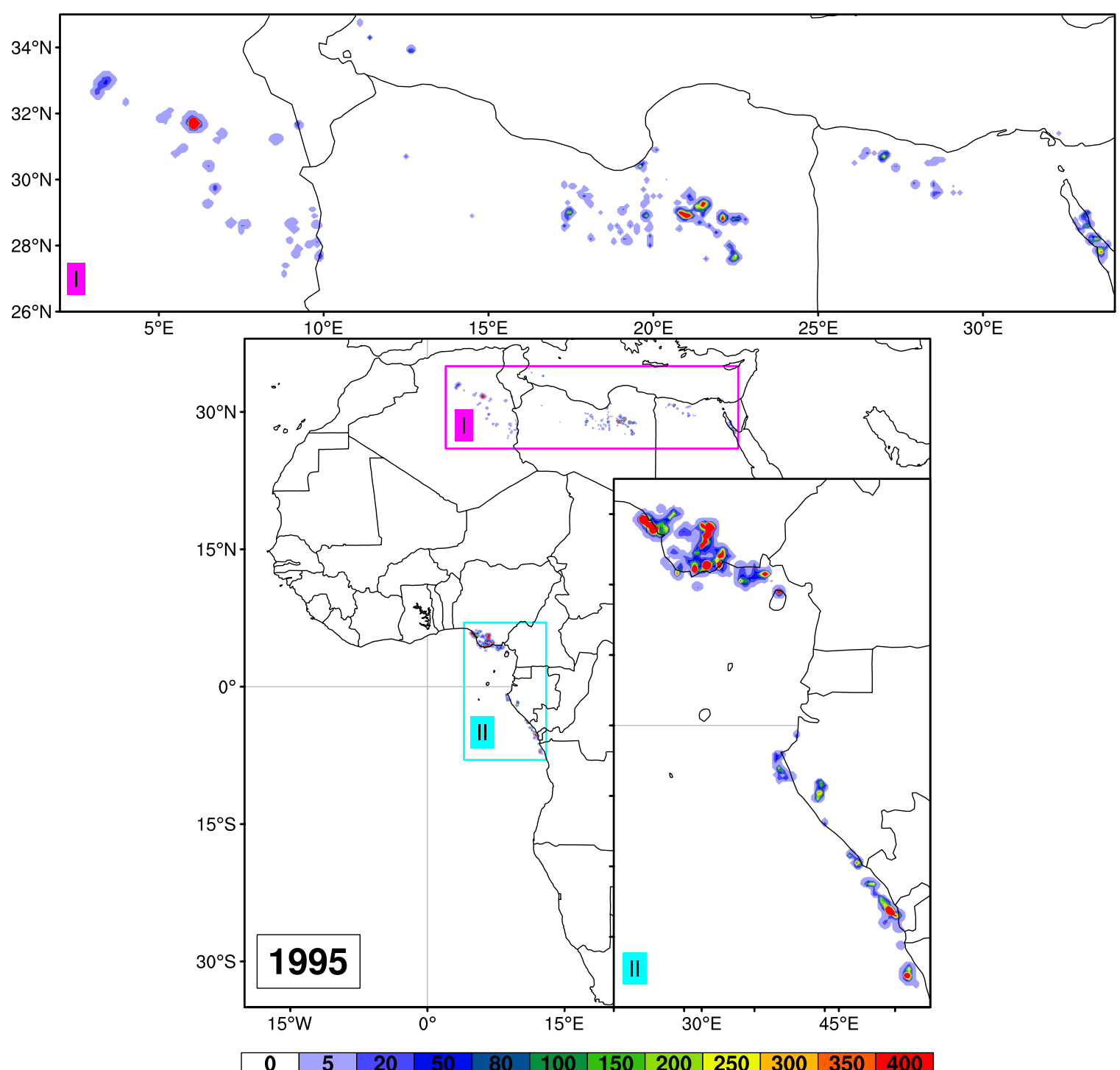

Figure 4: The spatial distribution of $\mathrm{CO}_{2}$ flaring emissions (in kiloton, kt) in 1995 as estimated in this study. There are two main flaring regions in Africa: region I located in the north (Algeria, Tunisia, Libya and Egypt) and region II in the southwest (Nigeria, Equatorial Guinea, Gabon, Democratic Republic of Congo and Angola). 


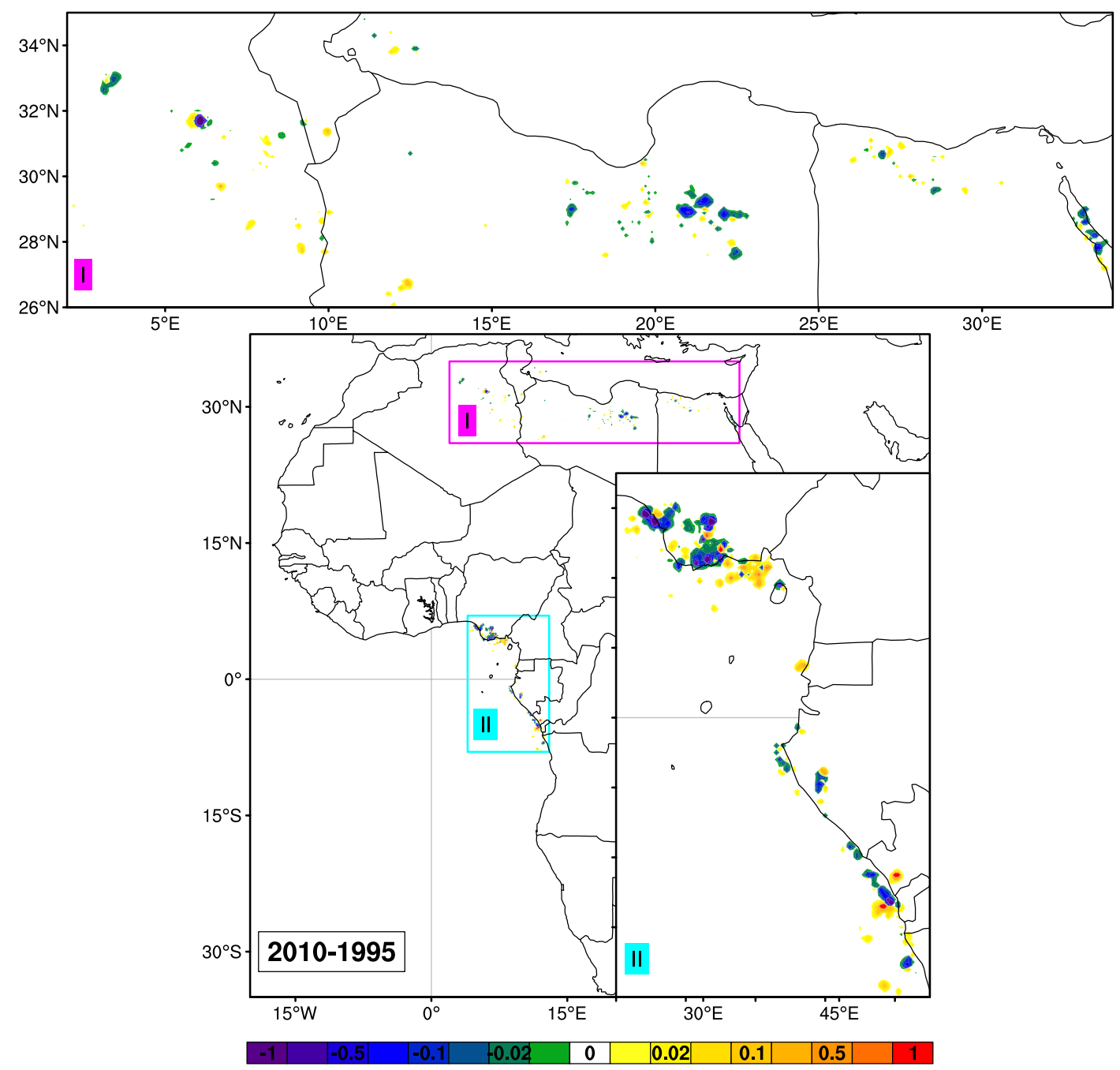

Figure 5: Spatial distribution of the difference in $\mathrm{CO}_{2}$ flaring emissions (in Teragram, $\mathrm{Tg}$ ) between 1995 and 2010 calculated in this study.

\subsection{National flaring emissions and trends}

384 In Figure 6 we present the average $\mathrm{CO}_{2}$ flaring emission levels for 1995, 2000, 2005 and 2010 385 for different countries in Africa, calculated using an average $\mathrm{CO}_{2} \mathrm{EF}$ of $2793.6 \mathrm{~g} / \mathrm{kg}$. The total 386 estimated $\mathrm{CO}_{2}$ flaring emission for Africa was approximately $150 \mathrm{Tg}$ in 1995 and decreased to about $100 \mathrm{Tg}$ in 2010 , a reduction of about $30 \%$. This decline is linked to the significant reduction of emissions in Nigeria from about $75 \mathrm{Tg}$ in 1995 to $42 \mathrm{Tg}$ in $2010(\sim 44 \%$ decrease), as well as in Algeria from about 26 to $15 \mathrm{Tg}$ ( $\sim 2 \%$ decrease) and Libya from 18 to $10 \mathrm{Tg}$ ( $44 \%$ decrease). Ismail and Umukoro (2012) found flaring emission of $44 \mathrm{Tg}$ of

$391 \mathrm{CO}_{2}$ in the Niger Delta in 2006, which is in reasonable agreement with the average emission 392 of $59 \mathrm{Tg}$ of $\mathrm{CO}_{2}$ obtained in this work for 2005. Figure 6 indicates that less significant 393 downward trends during this 15-years period were found in Egypt ( $\sim 30 \%)$, Gabon ( $20 \%)$ 
and Angola $(\sim 10 \%)$. These country-level decreases are in-line with the local decreases

395 mentioned above (and shown in Figure 5), and are largely driven by the fact that the impacts

396 of flaring have received more attention recently and corrective actions have been taken. Local

397 governments and international producers have taken necessary initiatives to limit the amount

398 of gas flared, including, for example, creating markets for selling the gas and putting it to

399 productive use. Furthermore, security issues in some countries during past years have led to a

400 decline in oil extraction and have contributed to decreased flaring. However, this is not the 401 case in all African countries. For example, $\mathrm{CO}_{2}$ flaring emissions in 2010 in South Africa, 402 Sudan, Tunisia and Equatorial Guinea increased by more than 50 \%, compared with 1995 403 levels. This is most certainly the result of increases in oil and gas production in these 404 countries since the 2000 s, as well as the lack of adequate infrastructure to commercialize the 405 gas currently flared.

406

407

408

409

410

411

412

413

414

415

416

417

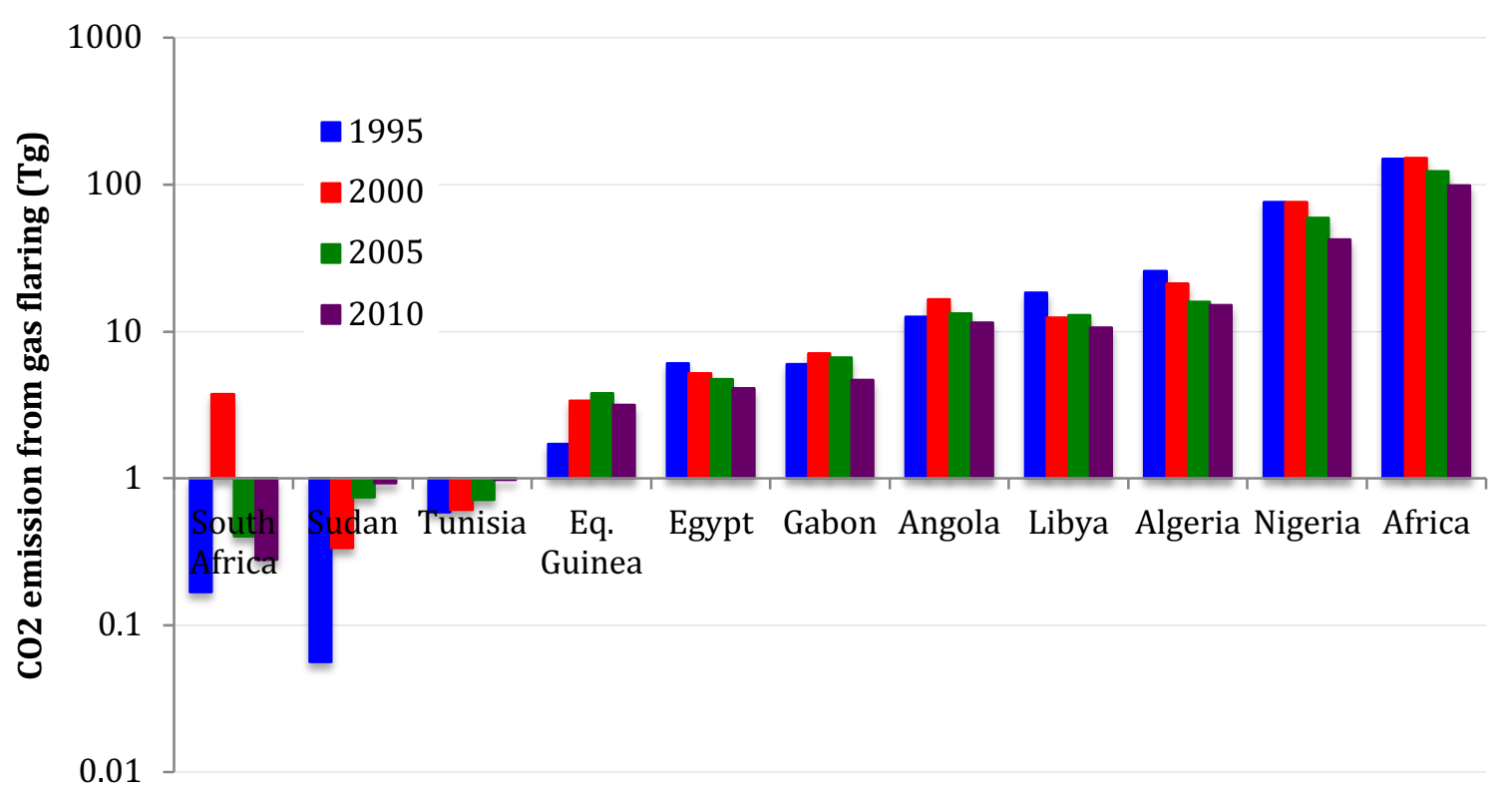

Figure 6: National trends of estimated $\mathrm{CO}_{2}$ flaring emissions. The emissions were calculated using an average $\mathrm{CO}_{2} \mathrm{EF}$ of $2793.6 \mathrm{~g} / \mathrm{kg}$ (Table 1).

Figure 7 shows the national contribution (in \%) to the total $\mathrm{CO}_{2}$ flaring emissions in Africa for 1995 and 2010. The $\mathrm{CO}_{2}$ emitted in Nigeria represents about $50 \%$ of the total amount flared in Africa in 1995. This contribution fell to approximately $40 \%$ in 2010, i.e. a $20 \%$ reduction from 1995. Algeria is the second contributor with a percentage of $17 \%$ in 1995 and $15 \%$ in 2010 . These two countries accounted for nearly $70 \%$ of Africa's total $\mathrm{CO}_{2}$ flaring emission in 1995 and $60 \%$ in 2010. The remaining 30 and $40 \%$, are mainly resulting from flaring activities in Libya and Angola (8-12 \%), Gabon (4-5 \%) and Egypt (3-4 \%). The main 
418 information from the Figure 7 is that the relative contribution of each country to the total 419 flaring in Africa has not changed significantly from year-to-year since 1995 and their 420 positions in the ranking of flaring regions remain unchanged.

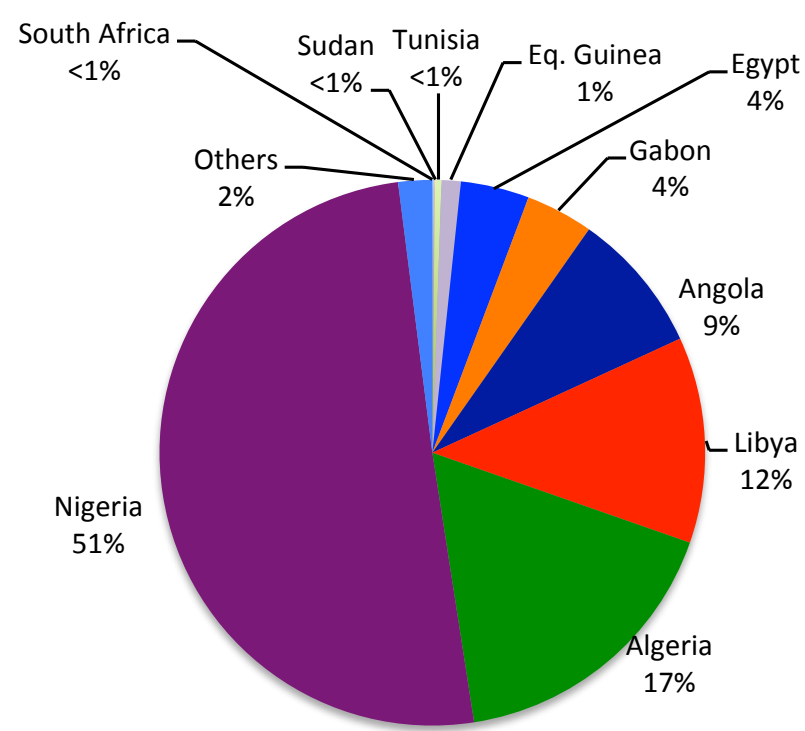

1995

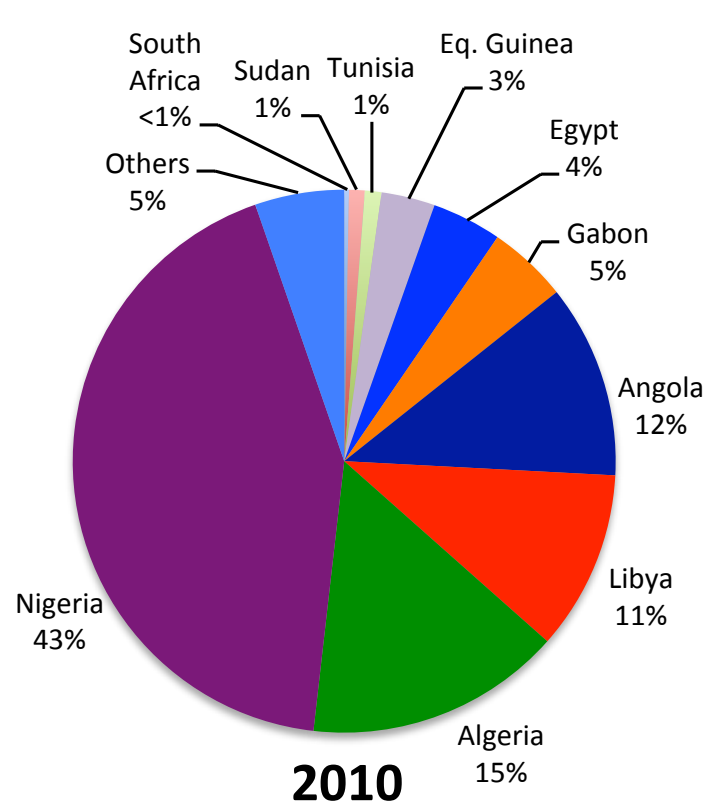

Figure 7: The contribution of each country to the estimated total $\mathrm{CO}_{2}$ flaring emissions in Africa. The emissions are calculated using an average $\mathrm{CO}_{2} \mathrm{EF}$ of $2793.6 \mathrm{~g} / \mathrm{kg}$ (Table 1).

\subsection{Comparison with current inventories}

428 Emissions estimated from this work are compared with the emissions from the ECLIPSE and EDGAR inventories, which are provided for different sectors including flaring. The main uncertainty in this comparison arises from differences in the exact definition of the emission sectors. ECLIPSE has been developed as part of the Evaluating the CLimate and air quality 432 ImPacts of Short-livEd pollutants project (Stohl et al., 2015). Version 5a provides baseline433 flaring emissions from 1990 to 2030 in five-year intervals at a $0.5^{\circ}$ x $0.5^{\circ}$ grid resolution (no $434 \mathrm{CO}_{2}$ data are available) (Klimont et al., 2017, in preparation). ECLIPSE estimations are based 435 on the location of flares from the World Bank's Global Gas Flaring Reduction initiative 436 (GGFR) (http://www.worldbank.org/en/programs/gasflaringreduction) combined with flaring 437 volumes from Elvidge et al., (2009). We also consider the EDGAR (Emissions Database for 438 Global Atmospheric Research) which has been developed by the Joint Research Center and 439 the PBL Netherlands Assessment Agency (Janssens-Maenhout et al., 2013). It provides emission of gases and particles at a $0.1^{\circ} \mathrm{x} 0.1^{\circ}$ grid resolution. We consider the emissions 
from version 4.2 (v4.2FT2010), which provides gridded emissions by sector including oil

442 production and refineries (referenced as 1B2a) for greenhouse gases (GHG), while version

4434.3 .1 is used for emissions for non-greenhouse gases.

444 The analysis focuses on region II as defined in Figure 5. Figure 8 displays the spatial 445 distribution in 2005 for $\mathrm{CH}_{4}$, the unique chemical species for which gridded emissions are 446 provided in all inventories. $\mathrm{CH}_{4} \mathrm{EFs}$ found in the literature vary between 2.5 and $45.0 \mathrm{~g} / \mathrm{kg}$, 447 thus the average emissions estimated in our work are calculated using an average EF of 19.2 $448 \mathrm{~g} / \mathrm{kg}$. Overall, results indicate a similar spatial pattern of distributions among the inventories. 449 Our maximum emission estimate over Africa is up to 10 times much lower than that of 450 ECLIPSE and about 3 times less than EDGAR (Figure 8). The dominate flaring areas in 451 Nigeria, Gabon, Democratic Republic of Congo and Angola are well represented in all three 452 maps. However, the exact location of the highest emissions and their magnitudes are quite 453 different in ECLIPSE, which is in part related to it's lower spatial resolution. Despite the good 454 agreement in spatial distribution, there are some notable discrepancies in emission peaks 455 between the three maps. For example, our estimates indicate peaks occurring at offshore 456 platforms in southern Nigeria which are not reproduced in EDGAR, and likewise, flares noted 457 at some onshore concessions in Nigeria, Cameroon and Angola are present only in the 458 EDGAR map and not in the other two. Sources for these discrepancies could be linked to 459 differences in the gas flaring shapefiles used in our analysis and ECLIPSE, and with the 460 removal of potential flare points during processing nighttime light files in our analysis. Other 461 inconsistences in hotspot emissions are observed in the ECLIPSE map (Figure 8, middle) at 462 Malabo Island in Equatorial Guinea where values are much higher than in Nigeria, which is 463 identified as the dominant flaring region in Africa. Furthermore, the EDGAR emissions 464 (Figure 8, right) show emissions covering the entire country of Equatorial Guinea, which 465 might be due to the presence of other sources different from flaring.

466 As previously mentioned, emissions determined in this work (Figure 5) increased or 467 decreased from 1995 to 2010 according to oil field locations. Similarly, EDGAR exhibits both 468 decreases in emissions in some areas between 2000 and 2010, as well as increases in some 469 countries such as Equatorial Guinea, Cameroon and Angola where local increases are 470 observed (figure not shown). In contrast, ECLIPSE indicates a decrease in all grid cells for the 471 period under study (1995-2010). Nevertheless, overall the temporal changes in EDGAR and 472 ECLIPSE are in agreement with the general reduction in flaring emissions estimated in this 473 work for most countries in Africa. 


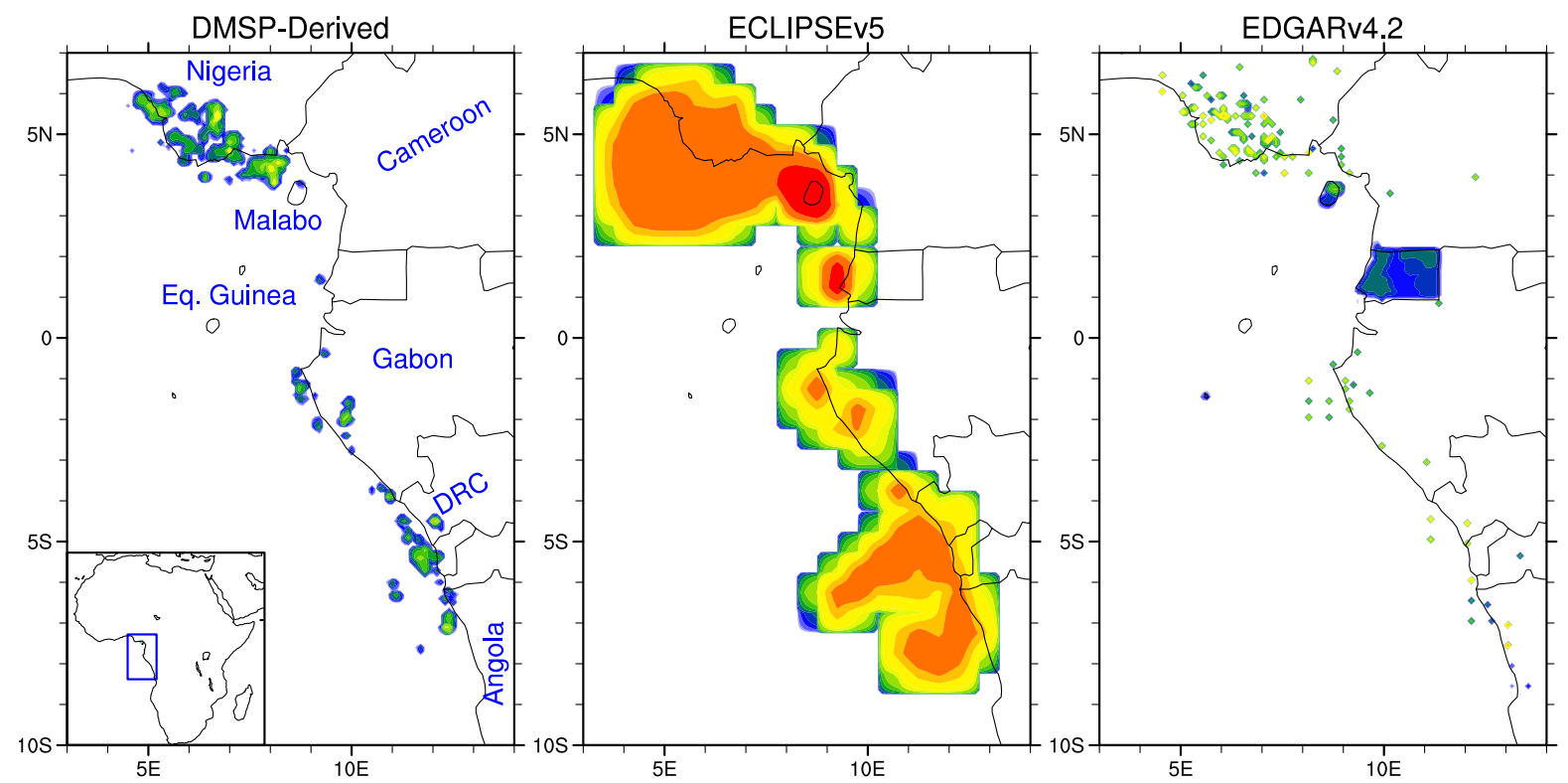

475

476

477

478

479

480

481

482

483

484

485

486

487

488

489

490

491

492

493

494

495

496

The calculation of regional emissions have been performed for the seven largest flaring countries together for the whole of Africa. Table 2 summarizes these emission estimates from different inventories and chemical compounds for 2005. In the table, the emissions estimated with the lowest and highest values of the emission factors from our work are shown. The total CO emissions in Africa as estimated using our method are in the range of $227-794 \mathrm{kt}$, with an average of $390 \mathrm{kt}$, and are in relatively good agreement with those of ECLIPSE and EDGAR4.3, 348 and $285 \mathrm{kt}$, respectively. ECLIPSE regional flaring emissions for CO (average values within the range of 11-108 kt) and $\mathrm{NO}_{\mathrm{x}}(2.2-21.6 \mathrm{kt}$ ) are within the same order of magnitude as the average estimations found in our study (11.9-187.7 kt for CO and 2.4-37.6 kt for $\mathrm{NO}_{\mathrm{x}}$ ), except for Equatorial Guinea, in which the ECLIPSE emissions (34 kt for $\mathrm{CO}$ and $6.9 \mathrm{kt}$ for $\mathrm{NO}_{\mathrm{x}}$ ) are about 3 times higher than our average estimations (11.9 kt and $2.4 \mathrm{kt}$, respectively). EDGAR4.3 emissions are also comparable with both ECLIPSE and our estimations, with values ranging from 8.5 to $133.9 \mathrm{kt}$ for $\mathrm{CO}$ and 1.6 to $24.4 \mathrm{kt}$ for $\mathrm{NO}_{\mathrm{x}}$. However, in Equatorial Guinea ECLIPSE emissions are up to 4 times larger than the $8.0 \mathrm{kt}$ of $\mathrm{CO}$ and $1.6 \mathrm{kt}$ of $\mathrm{NO}_{\mathrm{x}}$ estimates provided by EDGAR4.3. These regional discrepancies reflect the differences observed in the spatial distribution of $\mathrm{CH}_{4}$ emissions in Equatorial Guinea. Regarding average levels, the regional amount of emissions obtained in this study for BC (within the range of 1.7-27.4 kt) and $\mathrm{SO}_{2}(0.1-1.5 \mathrm{kt}$ ) are relatively consistent with those from 
ECLIPSE (2.6-25.1 kt and 0.02-1.4 kt, respectively). However, there are large differences in

498 Equatorial Guinea where the ECLIPSE emissions are notably higher than our estimations.

499 This may explain the differences in their total $\mathrm{BC}\left(\mathrm{SO}_{2}\right)$ emissions for Africa, which is 500 estimated at, on average $56.9 \mathrm{kt}(3.1 \mathrm{kt})$ in our study, $40.5 \mathrm{kt}(2.3 \mathrm{kt})$ by ECLIPSE. Both our 501 estimates and that of ECLIPSE are up to 90 times (6 times) higher than the EDGAR4.3 BC $502\left(\mathrm{SO}_{2}\right)$ emissions for most countries. OC emissions for all regions are higher in ECLIPSE (0.4$5034.9 \mathrm{kt}$ ) compared to EDGAR4.3 (less than $0.02 \mathrm{kt}$ ) and to lesser extent to our work (0.2-3.2 $504 \mathrm{kt}$ ). For OC, only one value for the EF has been found in the literature, thus no emission range 505 can be provided: the emissions of this chemical compound are very uncertain, because its EF 506 is derived from particulate matter and is not yet verified by direct or experimental 507 measurements.

$508 \mathrm{CH}_{4}$, which is known as the primarily component of natural gas, shows the largest differences 509 between the three datasets. For example, ECLIPSE (EDGAR4.2) regional $\mathrm{CH}_{4}$ flared are 15$51080(5-40)$ times higher than our mean estimations in all regions, with a ratio up to 40 (10) for 511 the whole of Africa. When considering the emissions determined using the highest value of 512 the EFs, these ratios are within the range of 5-20 and 2-10, when compared with ECLIPSE 513 and EDGAR4.2, respectively. The emissions of NMVOCs, which are also abundant in flared 514 gas, are 5-10 times larger in EDGAR 4.3 (96-851 kt) and to a lesser extent in ECLIPSE (67$515488 \mathrm{kt})$ than in our study (10-156 kt). When compared to our maximum estimations (20-319 $516 \mathrm{kt}$ ), the differences become only 2-4 times larger. The regional $\mathrm{CO}_{2}$ emissions resulting from 517 our lower estimations range from 3.7 to $42.1 \mathrm{Tg}$. The total amounts of flaring emissions in 518 EDGAR4.2 within the range of 2.4-37.6 Tg are consistent with our lower estimations, while our average values ranging from 3.8 to $59.4 \mathrm{Tg}$ are approximately $30 \%$ higher.

520 This comparison highlights how differences in the methodologies and data used have a large 521 impact on the quantification of flaring emissions. The large uncertainties in the EFs are 522 limiting and further direct measurements are needed to improve the estimation of flaring 523 emissions. 
Table 2: Comparison of flaring emissions of this work (DMSP-derived method), ECLIPSEv5a, EDGARv4.2 (FT2010) for GHG (CO and $\left._{2} \mathrm{CH}_{4}\right)$

526 and EDGARv4.3.1 for the other species in 2005. For this work, we provide a range of emissions using lowest and highest EFs from Table 1. The 527 unit is in kiloton $(\mathrm{kt})$.

\begin{tabular}{|c|c|c|c|c|c|c|c|c|c|}
\hline & & Algeria & Angola & Egypt & Gabon & Libya & Nigeria & Eq. Guinea & Africa \\
\hline \multirow{3}{*}{ ن } & This work & $29-102$ & $24-85$ & $9-30$ & $12-42$ & $24-83$ & $109-383$ & $7-24$ & $227-794$ \\
\hline & ECLIPSEv5a & 45 & 33 & 11 & 15 & 23 & 108 & 34 & 348 \\
\hline & EDGAR4.3 & 39 & 30 & 11 & 15 & 29 & 134 & 8 & 285 \\
\hline \multirow{3}{*}{$\overbrace{Z}^{\circ}$} & This work & $6.0-21.1$ & $5.0-17.5$ & $1.8-6.2$ & $2.5-8.7$ & $4.8-17.0$ & $22.3-78.6$ & $1.4-5.0$ & $46.3-163.3$ \\
\hline & ECLIPSEv5a & 9.1 & 6.8 & 2.2 & 2.9 & 4.7 & 21.6 & 6.9 & 69.7 \\
\hline & EDGAR4.3 & 7.0 & 5.4 & 1.9 & 2.7 & 5.3 & 24.4 & 1.6 & 51.9 \\
\hline \multirow{3}{*}{ ○ } & This work & 0.85 & 0.71 & 0.25 & 0.35 & 0.69 & 3.2 & 0.20 & 6.6 \\
\hline & ECLIPSEv5a & 2.1 & 1.6 & 0.52 & 0.69 & 1.1 & 5.0 & 1.5 & 16.1 \\
\hline & EDGAR4.3 & 0.005 & 0.004 & 0.001 & 0.002 & 0.004 & 0.019 & 0.001 & 0.04 \\
\hline \multirow{3}{*}{$\cup$} & This work & $0.80-18.2$ & $0.66-15.1$ & $0.24-5.4$ & $0.33-7.6$ & $0.64-14.7$ & $3.0-68.0$ & $0.19-4.3$ & $6.2-141.2$ \\
\hline & ECLIPSEv5a & 10.3 & 7.8 & 2.6 & 3.4 & 5.3 & 25.1 & 8.0 & 80.6 \\
\hline & EDGAR4.3 & 0.061 & 0.047 & 0.017 & 0.023 & 0.046 & 0.212 & 0.013 & 0.45 \\
\hline
\end{tabular}

\begin{tabular}{|c|c|c|c|c|c|c|c|c|c|}
\hline \multirow{3}{*}{ రి } & This work & $0.07-0.74$ & $0.06-0.61$ & $0.02-0.22$ & $0.03-0.31$ & $0.06-0.6$ & $0.28-2.8$ & $0.02-0.18$ & $0.57-5.7$ \\
\hline & ECLIPSEv5a & 0.60 & 0.45 & 0.02 & 0.20 & 0.31 & 1.4 & 0.46 & 4.5 \\
\hline & EDGAR4.3 & 0.06 & 0.05 & 0.02 & 0.02 & 0.05 & 0.28 & 0.01 & 0.48 \\
\hline
\end{tabular}

\begin{tabular}{|c|c|c|c|c|c|c|c|c|c|}
\hline \multirow{3}{*}{$\begin{array}{l}\text { O } \\
\sum \\
\sum\end{array}$} & This work & $17-85$ & $14-71$ & $5-25$ & $7-35$ & 14-69 & 64-319 & $4-20$ & $132-662$ \\
\hline & ECLIPSEv5a & 354 & 153 & 99 & 67 & 183 & 488 & 156 & 2,005 \\
\hline & EDGAR4.3 & 598 & 398 & 143 & 88 & 502 & 851 & 96 & 3,019 \\
\hline \multirow{3}{*}{ 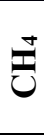 } & This work & $14-256$ & $12-213$ & $4-76$ & 6-106 & $11-207$ & $53-956$ & $3-61$ & $110-1,986$ \\
\hline & ECLIPSEv5a & 5,645 & 1,292 & 789 & 564 & 2,922 & 4,122 & 1,313 & 23,696 \\
\hline & EDGAR4.2 & 1,698 & 392 & 993 & 163 & 674 & 1,722 & 109 & 6,365 \\
\hline
\end{tabular}

\begin{tabular}{|c|l|c|c|c|c|c|c|c|c|}
\hline \multirow{2}{*}{$\delta$} & This work & $11,300-19,200$ & $9,300-15,900$ & $3,300-5,700$ & $4,700-7,900$ & $9,100-15,500$ & $42,100-71,500$ & $2,700-4,600$ & $87,379-148,523$ \\
\cline { 2 - 11 } & ECLIPSEv5a & - & - & - & - & - & - & - & - \\
\cline { 2 - 10 } & EDGAR4.2 & 11,000 & 8,400 & 3,000 & 4,200 & 8,300 & 37,600 & 2,400 & 80,737 \\
\hline
\end{tabular}




\subsection{Contribution of flaring to African anthropogenic emissions}

529 We have analyzed the contribution of flaring to the total anthropogenic emissions for different 530 countries in Africa. Table 3 shows the inventories used in this section: in addition to 531 ECLIPSE and EDGAR, we have also included the Liousse et al. (2014) and MACCity 532 (Granier et al., 2011) inventories of anthropogenic emissions over Africa. Note that these 533 latter two inventories do not include flaring emissions and were therefore not included in the 534 previous analysis. The relative importance of flaring is determined as the ratio between the 535 amount of flaring calculated in this work and the sum of the average of total anthropogenic 536 emission from the different inventories (excluding flaring) and the amount of flaring derived 537 in our study (from Table 2). Figure 9 shows the results for $\mathrm{BC}, \mathrm{CH}_{4}$ and $\mathrm{CO}_{2}$ emissions in 538 2005. Based on our minimum and maximum estimations, we estimate that BC emitted from 539 flaring accounted for between 1 to $15 \%$ (with an average of $7 \%$ ) of the total African 540 emission while the contribution of $\mathrm{CH}_{4}$ and $\mathrm{CO}_{2}$ ranged from 0.5 to $8 \%$ (with an average of 2 $541 \%$ ) and from 8 to $13 \%$ (with an average of $11 \%$ ), respectively. The contribution of flaring to 542 total African anthropogenic emission represent less than $1 \%$ for NMVOCs, OC, $\mathrm{CO}, \mathrm{SO}_{2}$ and $543 \mathrm{NO}_{\mathrm{x}}$ (not shown), illustrating their variability according to the species.

544 The importance of flaring also widely varies according to country. The minimum flaring 545 amounts of $\mathrm{BC}$ released into the atmosphere represented about $4 \%$ of the regional 546 anthropogenic emissions for Algeria and Angola, $2 \%$ for Nigeria, $8 \%$ for Libya and 547 Equatorial Guinea, $12 \%$ for Gabon and less than $1 \%$ for Egypt, South Africa, Sudan and 548 Tunisia (Figure 9, top left). When considering the estimated maximum flaring levels, these percentages are multiplied by a factor ranging from 5 to 20. In regions with low population 550 density such as Equatorial Guinea, Gabon and Libya, it can seen that BC are mainly emitted 551 from flaring activities with an average contribution up to 40, 50 and $45 \%$ of their regional BC 552 anthropogenic emissions, respectively. The average contribution estimated for Nigeria and 553 Angola are 1.5 to 3 times less. Our analyses indicate that BC flaring sources can not be 554 neglected in most of these African flaring countries. Its absence or underestimation seem to 555 support the large gap observed between the simulations and satellite observations of Aerosol 556 Optical Depth (AOD) over the flaring regions of the Guinea Gulf (Liousse et al., 2010 ; 557 Malavelle et al., 2011). The AOD, related to the amount of aerosol in the vertical column of 558 the atmosphere over an observation location, represents a suitable indicator of BC. Liousse et 559 al. (2010) reported that the ORISAM model has not captured the AOD hot spots observed by 560 the PARASOL satellite along the Guinean Gulf. They attribute this discrepancy to a possible 
561 missing source in the fossil fuel inventory used in the model. Malavelle et al. compared the 562 satellites-derived AOD from MISR, MODIS and OMI with AOD simulated by regional 563 climate model RegCM for different seasons averaged between 2001 and 2006. The model 564 simulates considerably lower AOD compared to observations over flaring areas of the Gulf of 565 Guinea. The authors reported that this underestimation of AOD by RegCM can be attributed 566 to inaccurate model transport of aerosols together with an underestimation of both dust and 567 biomass burning emissions.

568 This work shows that maximum annual $\mathrm{CH}_{4}$ flaring emissions in Africa is about $2.0 \mathrm{Tg} / \mathrm{yr}$ for 5692005 (Table 2), which corresponds to about $0.6 \%$ of the $324 \mathrm{Tg} / \mathrm{yr}$ global anthropogenic $\mathrm{CH}_{4}$ 570 emissions (Janssens-Maenhout et al., 2013). EDGAR $\mathrm{CH}_{4}$ emissions from oil and gas 571 production account for about $2 \%(6.4 \mathrm{Tg} / \mathrm{yr})$, while ECLIPSE estimations indicate a 572 contribution of about $7 \%(23.7 \mathrm{Tg} / \mathrm{yr})$. Nara et al., (2014) reported that $\mathrm{CH}_{4}$ from flaring 573 contributed to approximately $20 \%$ of worldwide anthropogenic emissions in 2010 . These 574 results reflect uncertainties inherent in the differences in approaches, as well as the emission 575 factors considered. From Figure 8 (top right), the current estimates suggest larger 576 contributions of $\mathrm{CH}_{4}$ emissions from oil and gas processes to the anthropogenic emissions at 577 the regional scale. For example, $\mathrm{CH}_{4}$ flaring emissions in 2005 account for an average $10 \%$ 578 of the regional anthropogenic emissions in Nigeria, Algeria and Angola, $30 \%$ in Libya, up to $57935 \%$ in Equatorial Guinea and Gabon, and less than $2 \%$ in the other countries.

580 Finally, the values of $\mathrm{CO}_{2}$ flaring emissions in Africa derived from this study range from 87 581 to $148 \mathrm{Tg} / \mathrm{yr}$, representing $0.3-0.5 \%$ of the EDGAR total $\mathrm{CO}_{2}$ anthropogenic emissions of $58229370 \mathrm{Tg} / \mathrm{yr}$ in 2005. Our estimation is in-line with that of EDGAR (0.3 \%). This means $\mathrm{CO}_{2}$ 583 from flaring has small impact to the global $\mathrm{CO}_{2}$ emissions. However, the analysis over Africa 584 reveals that the relative contributions of flaring in 2005 reached $50 \%$ of the regional 585 anthropogenic emissions in Nigeria and Angola for all values of emission factors (Figure 9, 586 bottom). In Gabon and Equatorial Guinea the contributions exceeded $50 \%$. Therefore, in 587 these African countries gas flaring dominated over its regional $\mathrm{CO}_{2}$ anthropogenic emissions, 588 especially along the Guinean Gulf. 
594 Table 3: Total anthropogenic emissions (kt) in Africa from various inventories for 2005.

595 Anthropogenic emissions of greenhouse gases are provided in EDGAR4.2 FT2010 while 596 emissions of the other chemical species come from EDGAR4.3.1.

597

\begin{tabular}{c|c|c|c|c}
\hline & Liousse et al. & MACCity & ECLIPSEv5a & EDGAR \\
\hline $\mathrm{CO}$ & 58,600 & 94,800 & 78,312 & 70,100 \\
\hline $\mathrm{OC}$ & 3,989 & 2,169 & 2,697 & 1,872 \\
\hline $\mathrm{BC}$ & 686 & 622 & 1,195 & 656 \\
\hline $\mathrm{SO}_{2}$ & 3,921 & 6,414 & 5,608 & 4,543 \\
\hline $\mathrm{NO}_{x}$ & 5,800 & 4,146 & 5,404 & 4,672 \\
\hline $\mathrm{NMVOCs}^{\mathrm{CO}}$ & - & 14,414 & 14,437 & 25,900 \\
\hline $\mathrm{CH}_{4}$ & - & - & - & 981,860 \\
\hline
\end{tabular}

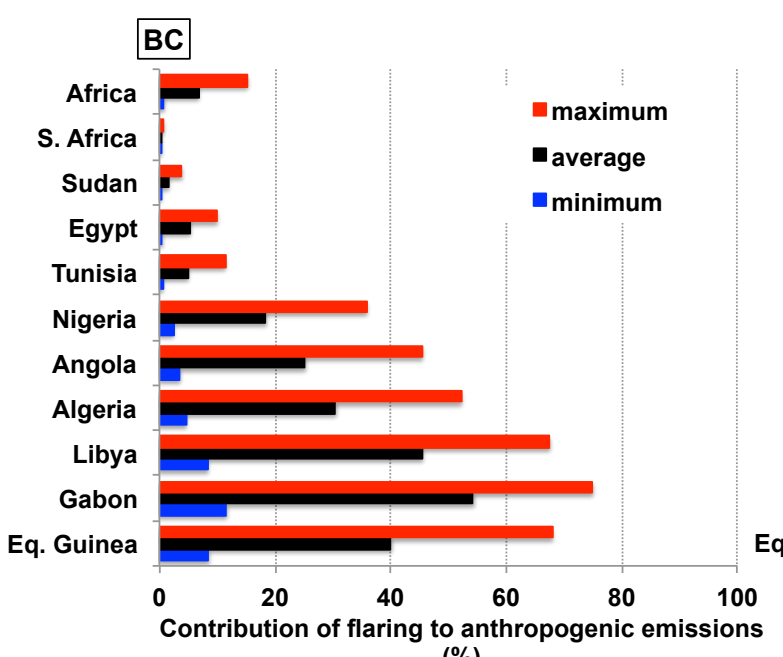

(\%)

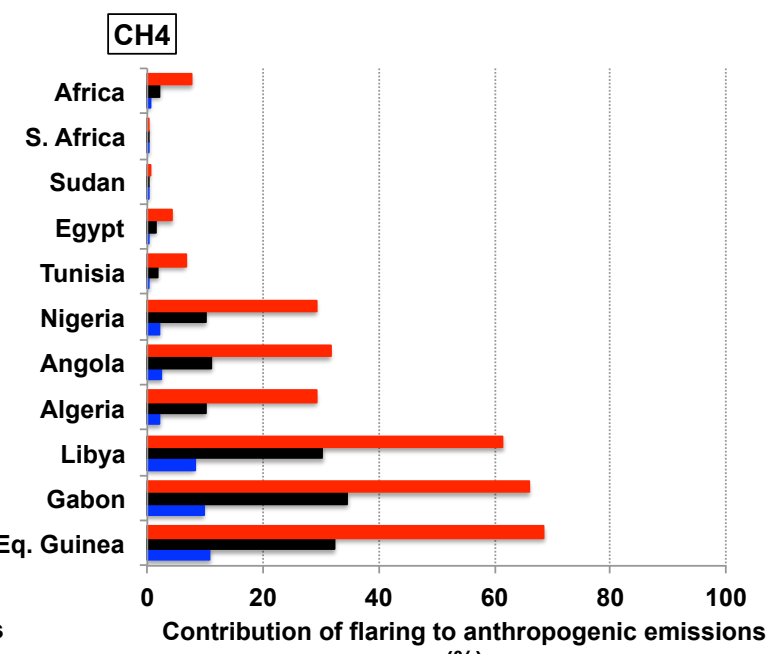

(\%)

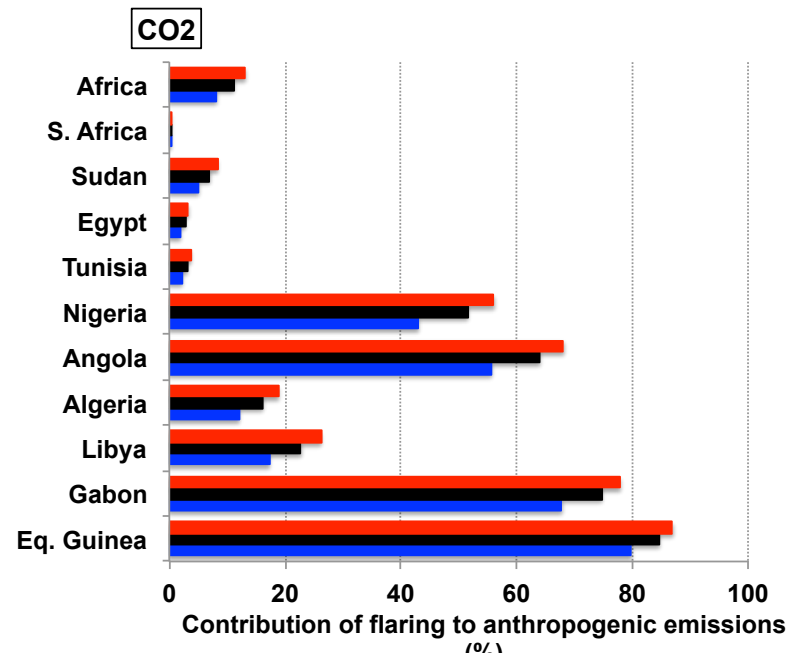

(\%)

Figure 9: Minimum, maximum and average percentage contribution of $\mathrm{BC}, \mathrm{CH}_{4}$ and $\mathrm{CO}_{2}$

600 flaring emissions in each country to the country total anthropogenic emission in 2005 . The top

601 value in each graph shows the percentage contribution of the total emissions from flaring in

602 Africa to the total anthropogenic emissions in Africa. 


\section{Conclusions}

604 Flaring is a major concern due to the large amount of gases and particulate matter emitted 605 during flaring activities. Despite the fact that it may represent an important pollutant source in 606 some regions, there are still only limited studies and inventories providing the spatial 607 distribution of emissions from flaring due to lack of real field measurements and systematic 608 field data publicly available. In this study, we have developed a method based on nighttime 609 light intensities combined with total regional flaring volumes from the U.S Defense 610 Meteorological Satellite Program (DMSP) data to provide spatial distributions over time 611 (1995-2010) of flaring emissions for several atmospheric chemical compounds. In this study, 612 it is estimated that flaring in Africa released on average $150 \mathrm{Tg}$ of $\mathrm{CO}_{2}$ emissions into the 613 atmosphere in 1995, and about $100 \mathrm{Tg}$ in 2010, indicating an overall downward trend (33\% 614 decrease) over the considered period. The results indicate that emissions have increased the 615 most at offshore platforms and, to a lesser extent, at some onshore oil fields, which we 616 attribute to the lack of regulations and the aging infrastructure of oil and gas fields. 617 Comparisons between our estimations to the ECLIPSE and EDGAR inventories, which 618 include flaring, show significant differences in the location of the major flaring areas, as well 619 as in their magnitudes. Results suggest that flaring accounted for 2,7 and $11 \%$ of the total $620 \mathrm{CH}_{4}, \mathrm{BC}$, and $\mathrm{CO}_{2}$ anthropogenic emissions over Africa, respectively, for the year 2005. The 621 impact of flaring on the anthropogenic emissions at the country level may be much more 622 important. For other chemical species, the estimated average contributions of flaring were too 623 low compared to the anthropogenic emissions (less than $1 \%$ for NMVOCs, OC, CO, NO and $624 \mathrm{SO}_{2}$ ). We have shown that the relative importance of flaring varies from one country to 625 another.

626 The quantification of emissions based on the amount of flared volumes and observations of 627 the nighttime light intensities from space has the advantage of improving the consistency of 628 time series and the representativeness of the local features in the emissions distributions. 629 Therefore, the methodology developed in this work can be extended to global data for the 630 same period of interest. Even if uncertainties remain large, especially due to emission factors, 631 this technique has the potential to provide more accurate emission data to improve the 632 performance of climate models in regions where flaring is important.

633 
Allen, D.T. and V.M. Torres, 2011. TCEQ 2010 Flare Study Final Report. Prepared for the Texas Commission on Environmental Quality. August 1. Available at: www.tceq.texas.gov/assets/public/implementation/air/rules/Flare/2010flarestudy/2010 -flare-study-final-report.pdf.

Canadian Association of Petroleum Producers: NPRI Guide - A Recommended Approach to Completing the National Pollutant Release Inventory for the Upstream Oil and Gas Industry, 2014.

CONCAWE, 2009: Air pollutant emission estimation methods for E-PRTR reporting by refineries'. Prepared by the Concawe Air Quality Management Group's Special Task Force on Emission Reporting Methodologies (STF-69), P. Roberts (technical coordinator). Report No 1/09, Brussels, January 2009.

Davoudi, M., Rahimpour, M.R., Jokar, S.M., Nikbakht, F., Abbasfard, H., 2013. The major sources of gas flaring and air contamination in the natural gas processing plants: A case study. J. Nat. Gas Sci. Eng. 13, 7-19. doi:10.1016/j.jngse.2013.03.002

Elvidge, C.D., Ziskin, D., Baugh, K.E., Tuttle, B.T., Ghosh, T., Pack, D.W., Erwin, E.H., Zhizhin, M., 2009. A Fifteen Year Record of Global Natural Gas Flaring Derived from Satellite Data. Energies 2, 595-622. doi:10.3390/en20300595

ESRI 2014. ArcGIS Desktop: Release 10.3. Redlands, CA: Environmental Systems Research Institute

Granier, C., Bessagnet, B., Bond, T., D’Angiola, A., Gon, H.D. van der, Frost, G.J., Heil, A., Kaiser, J.W., Kinne, S., Klimont, Z., Kloster, S., Lamarque, J.-F., Liousse, C., Masui, T., Meleux, F., Mieville, A., Ohara, T., Raut, J.-C., Riahi, K., Schultz, M.G., Smith, S.J., Thompson, A., Aardenne, J. van, Werf, G.R. van der, Vuuren, D.P. van, 2011. Evolution of anthropogenic and biomass burning emissions of air pollutants at global and regional scales during the 1980-2010 period. Clim. Change 109, 163-190. doi:10.1007/s10584-011-0154-1

Ismail, O.S., Umukoro, G.E., 2012. Modelling combustion reactions for gas flaring and its resulting emissions. J. King Saud Univ. - Eng. Sci. doi:10.1016/j.jksues.2014.02.003

Janssens-Maenhout, G., Pagliari, V., Guizzardi, D., Muntean, M., European Commission, Joint Research Centre, Institute for Environment and Sustainability, 2013. Global emission inventories in the Emission Database for Global Atmospheric Research (EDGAR): manual (I) - gridding: EDGAR emissions distribution on global gridmaps. Publications Office, Luxembourg.

Johnson, M.R., Devillers, R.W., Thomson, K.A., 2013. A Generalized Sky-LOSA Method to Quantify Soot/Black Carbon Emission Rates in Atmospheric Plumes of Gas Flares. Aerosol Sci. Technol. 47, 1017-1029. doi:10.1080/02786826.2013.809401

Johnson, M.R., Kostiuk, L.W., Spangelo, J.L., 2001. A Characterization of Solution Gas Flaring in Alberta. J. Air Waste Manag. Assoc. 51, 1167-1177. doi:10.1080/10473289.2001.10464348

Liousse, C., Guillaume, B., Grégoire, J.M., Mallet, M., Galy, C., Pont, V., Akpo, A., Bedou, M., Castéra, P., Dungall, L., Gardrat, E., Granier, C., Konaré, A., Malavelle, F., Mariscal, A., Mieville, A., Rosset, R., Serça, D., Solmon, F., Tummon, F., Assamoi, E., Yoboué, V., Van Velthoven, P., 2010. Updated African biomass burning emission inventories in the framework of the AMMA-IDAF program, with an evaluation of combustion aerosols. Atmos Chem Phys 10, 9631-9646. doi:10.5194/acp-10-96312010

Malavelle, F., Pont, V., Mallet, M., Solmon, F., Johnson, B., Leon, J.-F., Liousse, C., 2011. Simulation of aerosol radiative effects over West Africa during DABEX and AMMA SOP-0. J. Geophys. Res. Atmospheres 116, D08205. doi:10.1029/2010JD014829 
McEwen, J.D.N., Johnson, M.R., 2012. Black carbon particulate matter emission factors for buoyancy-driven associated gas flares. J. Air Amp Waste Manag. Assoc. 62, 307-321. doi:10.1080/10473289.2011.650040

McLennan, J., Williams, S., 2005. Deepwater Africa reaches turning point. Oil Gas J., ABI/INFORM Global 103, 18.

Nara Hideki, Hiroshi Tanimoto, Yasunori Tohjima, Hitoshi Mukai, Yukihiro Nojiri and Toshinobu Machida. Emissions of methane from offshore oil and gas platforms in Southeast Asia. Sci. Rep. 4, 6503; DOI:10.1038/srep06503 (2014).

Nwankwo, C.N., Ogagarue, D.O., 2011. Effects of Gas Flaring on Surface and Ground Waters in Delta State Nigeria. J. Geol. Min. Res. 3, 131-136.

Nwaogu, L.A., Onyeze, G.O.C., 2010. Environmental impact of gas flaring on EbochaEgbema, Niger Delta, Nigerian. J. Biochem. Mol. Biol. 25, 25-30.

Stohl, A., Aamaas, B., Amann, M., Baker, L.H., Bellouin, N., Berntsen, T.K., Boucher, O., Cherian, R., Collins, W., Daskalakis, N., Dusinska, M., Eckhardt, S., Fuglestvedt, J.S., Harju, M., Heyes, C., Hodnebrog, ø., Hao, J., Im, U., Kanakidou, M., Klimont, Z., Kupiainen, K., Law, K.S., Lund, M.T., Maas, R., MacIntosh, C.R., Myhre, G., Myriokefalitakis, S., Olivié, D., Quaas, J., Quennehen, B., Raut, J.-C., Rumbold, S.T., Samset, B.H., Schulz, M., Seland, ø., Shine, K.P., Skeie, R.B., Wang, S., Yttri, K.E., Zhu, T., 2015. Evaluating the climate and air quality impacts of short-lived pollutants. Atmospheric Chem. Phys. 15, 10529-10566. doi:10.5194/acp-15-10529-2015

Stohl, A., Klimont, Z., Eckhardt, S., Kupiainen, K., Shevchenko, V.P., Kopeikin, V.M., Novigatsky, A.N., 2013. Black carbon in the Arctic: the underestimated role of gas flaring and residential combustion emissions. Atmospheric Chem. Phys. 13, 88338855. doi:10.5194/acp-13-8833-2013

Talebi, A., Fatehifar, E., Alizadeh, R., Kahforoushan, D., 2014. The Estimation and Evaluation of New $\mathrm{CO}, \mathrm{CO} 2$, and NOx Emission Factors for Gas Flares Using Pilot Scale Flare. Energy Sources Part -Recovery Util. Environ. Eff. 36, 719-726. doi:10.1080/15567036.2011.584117

Torres, V.M., Herndon, S., Kodesh, Z., Allen, D.T., 2012. Industrial Flare Performance at Low Flow Conditions. 1. Study Overview. Ind. Eng. Chem. Res. 51, 12559-12568. doi:10.1021/ie202674t

Waldner, C.L., Ribble, C.S., Janzen, E.D., Campbell, J.R., 2001. Associations between oiland gas-well sites, processing facilities, flaring, and beef cattle reproduction and calf mortality in western Canada. Prev. Vet. Med. 50, 1-17. doi:10.1016/S01675877(01)00214-8

Weyant, C.L., Shepson, P.B., Subramanian, R., Cambaliza, M.O.L., Heimburger, A., McCabe, D., Baum, E., Stirm, B.H., Bond, T.C., 2016. Black Carbon Emissions from Associated Natural Gas Flaring. Environ. Sci. Technol. 50, 2075-2081. doi:10.1021/acs.est.5b04712

Wilk, M., Magdziarz, A., 2010. Ozone effects on the emission of pollutants coming from natural gas combustion. Pol. J Env. Stud 19, 1331-1336. 